\title{
HAJI BUDAYA DAN BUDAYA HAJI
}

\author{
Abdullah \\ Jurusan Aqidah dan filsafat \\ Fakultas Ushuluddin dan Filsafat UIN Alauddin \\ E-mail: abdullahdul687@gmail.com
}

\section{Abstrak}

Haji sebagai budaya dan budaya dalam berhaji perspektif sosio-filosofis, menjadi tradisi yang serius diteliti dalam kehidupan keberagamaan dewasa ini, sebab dalam upacara ritual berhaji terkadang sebagian jamaah melupakan makana substansi atau ontologism dalam berhaji itu sendiri. Seharusnya para pelaksana haji sedapat mungkin memahaminya secara dhahiriyah dan bathiniyah atau teks dan konteks dalam pelaksanaan haji. Dalam peneluusuran tulisan ini menemukan Pertama, Haji budaya adalah pelaksanaan haji yang dilakukan oleh setiap umat Islam yang berkemampuan totalitas, secara hakiki ritualistik, spiritualistik dan nilai-nilai sosialistik yang dilakukan oleh orang-orang yang berhaji adalah sebuah budaya. Kedua, Para pelaksana haji baik yang berkemampuan lebih atau yang memaksa diri dalam rangka meraih tingkatan mabrur sebatas pada ritualisme belaka dan tidak memberikan nilai implikasi dari ke-hajiannya, merupakan budaya haji yang hura-hura mengejar prestise bukan prestasi dan kualitas. Hal inilah yang merusak kehidupan kemanusiaan secara individu dan kelompok seperti melakukan penyimpangan sepulang dari melaksanakan haji antara lain korupsi, kolusi dan nepotisme yang tidak wajar untuk dilakukan oleh para haji-haji.

\section{Keywords}

Haji Budaya, Budaya Haji, dan sosio-filosofis

\section{Pendahuluan}

Perspektif syariah melaksanakan ibadah haji merupakan proses penyempurnaan keislaman seseorang secara totalitas. Ibadah Haji diwajibkan hanya satu kali dalam setahun. Apabila terdapat seseorang dalam melaksanakan haji 
lebih dari sekali, dihukum sunat. Tetapi realitas keindonesiaan terdapat sebagian umat Islam khususnya di kalangan berduitapakah ia pedagang, pemerintah maupun penguasa- sering melakukan ibadah haji dengan berkali-kali.

Bagaimana persoalan yang dihadapi kini dan disinian tentang haji banyak kali di Indonesia?. Apa masih disebut haji rutinitas atau merupakan sebuah trend budaya ${ }^{1}$ muslim masa kini?. Jikalau haji sebagai rutinitas atau trend budaya sebaiknya sedini mungkin untuk direinterpretasi telelologisnya. Haji yang dilakukan oleh semua orang yang berkemampuan, puncaknya adalah mencapai kearifan, ketika mereka bertafakur pada halte Arafah. Kearifan yang dimaksud adalah kearifan ritual doktrin keagamaan, sosial kemasyarakatan- memberikan nilai produkivitasnya dan kearifan spiritual.

Dapatkah bagi yang berkemampuan atau yang berduit dalam melaksanakan haji lebih dari satu kali dirubah menjadi satu kali atau uang yang bekelebihan itu akan diarahkan kepada persoalan sosial kemasyrakatan? Oleh karena itu pada makalah ini akan mengemukakan beberapa permasalahan sebagai berikut: Bagaimana alternatif ekonomis bagi budaya haji lebih dari sekali terhadap kesejahteraan umat?

${ }^{1}$ Budaya berasal dari kata budi artinya tahu/pengetahuan dan daya artinya kekuatan. Kebudayaan menurut E.B.tylor (1880) berkata bahwa kebudayaan adalah kompleks ari berbagai kemampuan dan kebiasaan yang diperoleh oleh manusia sebagai anggota masyarakat termasuk pengetahuan, kepercayaan, seni moral, hukum dan kebiasaan. Lihat, Darmawan Mas'ud Rahman, Konsep Kebudayaan Islam di Dalam Budaya Nasional dan Global (Suatu Kajian Teoritik Menggugah Definisi Budaya Masa Kini Untuk Masa Mendatang) Orasi Ilmiah Pengukuhan Jabatan Guru Besar Disampaikan Pada Dies Natalis XXXV (IKIP Ujungpandang tanggal 1 Agustus 1996), h. 8

TAHDIS Volume 10 Nomor 1 Tahun 2019 


\section{Haji Sebagai Roh Budaya}

Haji budaya $^{2}$ adalah bagian dari fitrah manusia, jika budaya $^{3}$ dipahami secara hakiki, bukan budaya dalam konteks sosiologis. Pelaksanaan haji merupakan keharusan spiritual manusia, karena visi haji yang diinginkan dan diraih secara filosofis adalah mencapai puncak kearifan. Mencapai tingkat kearifan merupakan kebutuhan dasar manusia di dalam fitrahnya. Karena itu manusia yang telah mencapai tingkat kearifan puncak maka ia telah terkategori ke dalam manusia berbudaya. Sedangkan bagi kelompok manusia yang memandang haji sebagai proses penyelesaian ritualisme keislaman mereka, maka hajinya itu belum mencapai tingkatan haji berbudaya atau belum mengenal apa artinya sebuah kearifan, tetapi mereka baru memahaminya sebatas wisata budaya yang penuh hura-hura ${ }^{4}$.

Apabila kita mengkaji lebih mendalam baik dari aspek epistemologis maupun aksiologis tentang perjalan historitas haji ini, kita selalu terkenang pada sebuah kisah pencarian Tuhan yang dilakukan oleh nabi Ibrahim as. Penemuan Ibrahim menyebabkan manusia yang tadinya tunduk kepada alam makrokosmos menjadi mampu menguasai alam semsta

2 Haji budaya merupakan pelaksanaan haji yang lahir dari pertimbangan suci dari fitrah manusia dengan tujuan suci mencapai tingkat kesucian kepada yang Maha suci, inilah yang penulis istilahkan haji yang memiliki pertimbangan axiokultural ke- manusia-an yang visinya adalah mencapai tingkat keaifan baik spiritual, sosial maupun ritual dan kesalehan ekologis.

3 Kebudayaan menurut Ibn Khaldun adalah hasil penalaran yang tinggi melalui pertimbangan yang logis dan membedakan manusia dengan binatang, ibid, h. 9

4 Pelaksanaan haji pada tingkat ini belum memahami visi dan misi haji, hal inilah yang menyebabkan seseorang terkadang ditemukan sepulang dari hajinya itu masih melakukan kecurangan atau penyimpangan sosial dan spiritual.

TAHDIS Volume 10 Nomor 1 Tahun 2019 
(antroposentris) serta dapat menilai baik dan buruknya sesuatu.

Penemuan roda kehidupan dan lain-lainnya itu menjadikan manusia melakukan kesewenang-wenangan di muka bumi ini, tetapi jika roda kehidupan itu diemukan oleh manusia yang memiliki konsep ontologis dirinya maka ia tetap menjadi mahluk mulia. Penemuan bapak monoteisme ini tentang Tuhan, bukan saja Tuhan untuk segolongan manusia tetapi seluruh lapisan manusia baik dari segi ras, budaya, maupun kelompok. Tuhan yang dimaksud adalah Tuhan Universal.

Ajaran nabi Ibrahim yang dilakonkan bersama putranya Ismail as itu (mulai dari membangun ka'bah sampai kepada diwajibkan seluruh umat Islam untuk mengikuti ritual yang dilakukannya itu). Dengan dasar itu hukum haji adalah wajib ولله على الناس حجّ البيت مناستطاع اليه سبيلا (Hanya karena Allahlah haji itu diwajibkan kepada manusia, yaitu barang siapa yang mampu berziarah ke Baytullah).Kewajiban seperti ini menjadi pedoman hidup dan kehidupan bagi masyarakat haji di kemudian hari yang pada hakekatnya memberikan ajaran inti. Pertama, Pengakuan akan keesaan Tuhan serta penolakan segala macam dan bentuk kemusyrkan, baik berupa patung, bintangdan lain-lain, Kedua, Keyakinan tentang adanya neaca keadilan Tuhan dalam kehiduan ini dan puncaknya akan diperoleh setiap mahluk ketika di hari kebangkitan nanti. Ketiga, Keyakinan entang kemanusiaan yang bersifat universal, tiada perbedaan dalam kemanusiaan seseorang dengan lainnya. ${ }^{5}$ Ketiga inti ajaran ini tercermin dengan jelas atau dilambangkan dalam praktek-praktek haji ajaran Islam.

5 M.Qurash Shihab, Membumikan Al-Quran : Fungsi dan Peran Wahyu dalam Kehidupan Masyarakat, (cet; 13, Bandung;Mizan, 1996), 333

TAHDIS Volume 10 Nomor 1 Tahun 2019 
Mengenai masalah yang berkaitan dengan poin ketiga, bahwa haji melambangkan persaman nilai kemanusiaan yang hakiki, dapat kita lihat dari rukun haji seperti melaksanakan wukuf di arafah. Pelaksanaan wukuf di rafah ini memerika keyakinan kepada kita bahwa di tempat itu semua manusia berkumpul dan bersimbuh mengahadap kepada Tuhan yang Esa. Mereka datang dari erbagai latar belakang ras, suku, bangsa dan bahasa yang berbeda. Oleh karena itu haji memerikan nilai kemanusiaan yang universal tidak hanya dapat diprktekkan di tanah Arab atau di Mekah ketika menunaikan haji saja, tetapi bagaimana nilai arafah terhadap sejumlah manusia di seluruh dunia itu dapat dipraktekan kembali di daerah masing-masing ketika nafsi-nafsi itu kembali ke daerahnya.

Dalam pelaksanaan haji terdapat pula nilai-nilai kemanusiaan universal. Tentunya makna kemanusiaan dalam pelaksanaan haji budaya ini tidak hanya terbatas pada persamaan nilai kemanusiaan. Ia mencakup seperangkat nilainilai luhur yang yang seharusnya menghiasi jiwa pemiliknya. Ia bermula dari kesadaran akan fithrah [jati diri]-nya serta keharusanya menyesaikan diri dengan tujuan kehadiran dipentas bumi ini.

Kemanusian mengantarkan putra putri adam untuk menyadari arah yang ditujuh serta perjuangan mencapainya. Kemanusiaan menjadikan mahluk ini memiliki moral serta berkemampuan memimpin mahluk-mahluk lain dalam mencapai tujuan penciptaan. Kemanusian mengantarkan untuk menyadari bahwa ia adalah mahluk dua dimensi yang harus melanjutkan evolusinya hingga mencapai titik akhir.

Kemanusiaan mengantarkannya untuk sadar bahwa ia adalah mahluk sosial yang tidak dapat hidup sendirian dan harus bertenggang rasa dalam berinterasi. Makna-makna di 
atas dipraktekan dalam pelaksanakan ibadah haji, baik dalam acara ritual atau dalam tuntunan non ritualnya, dalam bentuk kewajibannya atau larangan, dan dalam bentuk nyata atau simbolik. Kesemuanya itu pada akhirnya mengantarkan jamaah haji hidup dalam pengalaman dan pengalaman manusia universal. Berikut ini akan dikemukakan secara sepintas kilas beberapa hal yang berkaitan dengannya;

Pertama, Ibadah haji dimulai dengan niat sambil menanggalkan pakaaian biasa dan mengenakan pakaian ihram. Tidak dapat disangka bahwa pakaian menurut kenyataannya dan juga menurut Al-Qur'ān, berfungsi antara lain, sebagai pembeda antara seseorang atau sekelompok dengan lainnya, perbedaan status sosial ekonomi atau profesi. Pakaian dan juga dapat memberi pengaruh psikologis kepada pemakaiannya.

Di miqat makaniy, tempat ritual ibadah haji dimulai dengan perbedaan dan pembedaan tersebut harus di tanggalkan sehingga semua harus memakai pakaian yang sama. Pengaruh-pengaruh psikologi yang melekat dari pakaianpun harus ditangalkan sehingga semua merasa dalam satu kesatuan dan pesamaan.

Di Miqat ini apapun ras, suku, bahasa dan bangsamu lepaskan semua. Bentuk pakaian yang engkau kenakan seharihari baik sebagai seekor serigala, yang melambangkan kekejaman dan penindasan, tikus yang melambangkan kelicikan, dan sifat seekor anjing melambangkan tipu daya muslihat, penjilat atau seperti sifat seekor domba yang melambangkan bentuk penghambaan kepada sesama yang tidak pantas. Tanggalkan semua itu di mikat dan berperanlah sebagai manusia yang sesungguhnya.

Di mikat ini dengan menggunakan dua helai pakaian yang berwarna putih sebagaimana yang akan membalut tubuh ketika mengahiri perjalanan hidup di permukaan dunia ini, 
seeorang yang melaksanakan ibadah haji akan atau seharusnya dipengaruhi oleh pakaian ini. Seharusnya ia merasakan kelemahan dan keterbatasaannya serta pertanggungjawaban yang akan ditunaikan kelak di hadapan Tuhan Yang maha Kuasa, yang disisiNya tiada perbedaan antara seseorang dengan yang lain kecuali atas dasar pengabdian kepadNya

Kedua, Dengan menggunakan pakaian ihram, maka sejumlah larangan-larangan yang haus ditaati oleh para jemaah haji mulai diindahkan. Bentuk larangan dimaksud adalah dilarang bersetubuh dengan Isteri, larangan melakukan kejahatan, larangan bertengkar, larangan berpakaian yang berjahit, khusus perempuan dilarang menutup wajah, dilarang melangsungkan akad nikah atau proses pernikahan, dilarang memotong kuku tanpa uzur, dilarang memakai wewangian, dilarang berburu, mencabut rumput atau memotong pohon lain.

Tujuan daripada ini semua adalah karena manusia berfungsi memelihara mahluk-mahluk Tuhan serta memberinya kesempatan seluas mungkin untuk mencapai tujuan penciptaannya. Dilarang juga menggunakan wewangian agar supaya para peserta haji dapat memahami dan menyadari bahwa manusia bukan materi semata-mata, bukan pula birahi, dan bahwa hiasan yang dinilai Tuhan adalah hiasan Rohani6

Dalil yang menerangkan tentang ihram dan laranganlarangannya dijelaskan Allah dalam firmanNya yang tercantum dalam Qs;2 ayat 197.

$$
\text { فمن فرض فيهنّ الحجّ فلا رفث ولافسوق ولاجدال فالحبّ ...... }
$$

6 Dilarang juga menggunting rambut dan kuku masing-masing menyadari jati diri nya menghadap Tuhan sebagaimana apa adanya, Lihat M.Quraish Shihab, Membumikan Alquran :Fungsi dan Peranan Wahyu Dalam kehidupan Masyarakat (Bandung:Mizan,1996),h.36

TAHDIS Volume 10 Nomor 1 Tahun 2019 
Terjemahnya

Barang siapa yang telah berihram pada bulan-bulan tersebut, tidak boleh ia melakukan senggama, fasik dan bertengkar sewaktu mengerjakan ibadah haji...

Barang siapa yang mampu menjaga hal itu, maka ia akan dibebaskan dari dosa-dosa sebagaimana sejak ia dilahirkan.

Ketiga, Ka'abah yang dikunjungi mengandung pelajaran yang amat berharga bagi segi kemanusiaan. Di sana ada hijir Ismail, secara harfiah pengakuan Ismail untuk membangun ka'ah sebagai pusat untuk mempesatukan umat Islam sedunia. Di situ tidak ada perbedaan antara hamba budak dan non budak semuannya sama di sisi Allah swt.

Keempat, di Arafah, padang yang luas lagi gersang itu, seluruh jemaah haji berhenti sampai terbenam matahari. Di sini mereka melakukan wukuf, Mengenai wukuf di Arafah Alquran surah 2 ayat 198 menjelaskan;

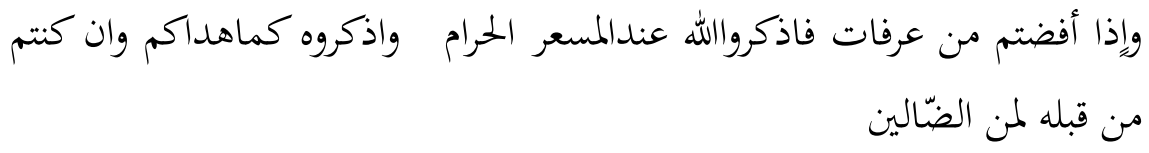

Terjemahanya

Jika kamu telah bertolak dari Arafah, berzikirlah pada Allah di Masy'aril Haram (Bukit Quzah), dan berzikirlah sesuai dengan petunjuknya kepadamu, sesungguhnya kamu sebelum itu termasuk orang yang sesat. (Qs 2:198)

Kata وإِذا أفضتم من عرفات, jika kamu melimpah, yaitu bertolak dari Arafah ramai-ramai, tidak sendiri-sendiri. Jamaah keluar dari Arafah setelah maghrib tanggal 10 Dzulhijjah, seperti air yang tumpah dari sebuah bejana-beramai-ramai. Kata عرفات, ada beberapa pendapat mengapa dinamakan Arafah.pertama setelah jidril menuntun Ibrahim melaksanakan haji, mulai dari thawaf-sa'I - Mina- muzdalifah -Arafah, Jibril 
bertanya apakah Ibrahim telah mengetahui apa yang diperlihatkan? Menjawablah jibril Ya, yaitu Arafah. Istilah ini ada kaitannya dengan doa nabi ibrahim, وارنامناسكن , ajarkanlah kami cara-cara ibadah haji.

Kedua, Dinamakan Arafah karena tempat itu merupakan pusat perkenalan manusia sedunia. Ketiga, karena tempat itu Adam dan Hawa bertemu dan saling berkenalan setelah saling mencari sewaktu Adam diturunkan di india dan Hawa di jeddah. Keempat, mengandung arti bersih.

Pelaksanaan wukuf di Arafah ini, kata memiliki ketentuan, yaitu seseorang wukuf di arafah sesudah tergelincir matahari (selesai zawal) pada hari Arafah dan keluar meninggalkan Arafah sebelum Magrib maka wukufnya dianggap syah. Di tempat ini mengandung makna sebagai tempat memakrifah pejalanan hidup kemanusiaan universal. Di tempat ini hendaklah para jemaah haji sadar akan kehidupan seagai hamba Allah dan sosial kemasyarakatan secara arif dan bijak.

Dari arafah ini, jemaah haji terus ke mujdalifah untuk mengumpulkan senjata dalam menghadapi musuh utama yaitu setan. Di sanalah manusia elakukan peleparan, di mana yang dilempar adalah sifat-sifat setan yang ada pada setiap diri jemaah yang harus di buang jauh-jauh. Perintah melempar jemarat ini juga bagian dari ajaran nabi Ibrahim as sebagaimana dijelaskan Rasulullah di setiap melemparan membaca takbir

Allah maha Agung, Ya Allah jadikanlah haji ini mabrur dan dosa yang diampuni.

Jika sudah selesai jumrah 'aqabah (kubra) yaitu setan terbesar, maka halalah seluruh yang diharamkan selama ihram, kecuali bergaul dengan isteri/suami, wangi-wangian dan berburu.

TAHDIS Volume 10 Nomor 1 Tahun 2019 


\section{Budaya Haji Berimplikasi Haji Prestise}

Istilah budaya haji pada bagian ini, penulis lebih terkonsentrasi pada budaya dalam pengertian budaya ritualisme. Dari aspek sosiologis, tentang budaya haji dalam konteks keindonesiaan secara umum belum menggambarkan adanya spirit kehajian secara esensial. Hal ini sangat dipengaruhi kondisi sosial kultural masyarakat Islam Indonesia. Faktor inilah yang menjadi alasan penulis mengkategorikan budaya haji sebagai haji prestise -yang mengejar nilai starata sosial di tengah masyarakat. Sekelompok muslim yang memahami dan mengamalkan haji sebatas rutinitas ritualitas keislaman, akan berdampak sebatas pada aspek kognitif dan kurang memberikan aplikasi sosial kemasyarakatan, yang maksimal. Karena itu pelaksanaan haji demikian masuk pada kategori budaya haji secara sosiologis dan kultural. Maksudnya mereka tetap melaksanakan haji, tapi bukan pada tataran haji hakikat tetapi haji sosial- yang konon hanya sebatas ingin memperoleh mabrur secara sosial atau ingin memperoleh prestise bukan sebuah haji berprestasi ritual, spiritual, sosial dan totalitas kehambaan.

Orang melaksanakan haji sekedar ritual (haji kemasan) tanpa memperhatikan spiritual dan sosial, akan mendapat sorotan, kritikan atau cacian jika sepulang dari haji masih melakukan penyimpangan dan perusakan baik dalam bentuk ringan maupun yang berat seperti monopoli jabatan bagi arah pejabat, eksploitasi kekayaan alam bagi para ekonom, pembututan dan pembobolan uang kalangan pebankan serta menjalankan perpolitikan busuk dalam menjalankan aturan roda kepemerintahan.

Oleh karena itu menurut teori sosiologi bahwa seseorang yang memahami haji pada tingkat kesalehan ritual maka belumlah sempurna secra komprehensif, tetapi ia harus 
memahmi dan menangkap makna yang terdalam daripada haji yang ia telah lakukanya.

Posisi sebagai haji mabrur adalah dambaan semua calon jemaah haji yang hendak berangkat ke tanah suci. Tetapi hendaklah diingat bahwa haji mabrur itu tidak semata-mata mengejar surga seperti yang berulang-ulang disampaikan oleh sesuatu yang bersifat eskatologis. Haji mabrur juga harus punya dampak kekinian dan kedisinian.

Seseorang yang sudah bertitel haji seharus -nya menjadi teladan moral bagi lingkungannya. Posisi ideal inilah yang tidak mudah kita temukan dalam kehidupan kolektif bangsa kita. Sebagian orang yang sudah menunaikan haji tidak mengalami transformasi moral apa-apa. Bahkan setelah haji sikap rakusnya terhadap harta haram semakin bertambah. Seakan-akan dia berfilsafat "naik haji adalah tugas agama, sementara korupsi adalah profesi"7.

Tentunya jumlah para haji yang terlibat dalam korupsi tidaklah banyak tetapi data sosiologis kita menunjukkan bahwa diantara koruptor Indonesia ada yang menyandang titel haji. Bahkan setelah meninggal, masyarakat dibuatnya heboh karena hasil korupsinya menjadi rebutan. Pondasi moral yang rapuh merupakan sebab utama mengapa setelah hampir setengah abad kita merdeka, budaya korupsi, penyelewengan dan sebangsanya itu, tampaknya belum juga mencapai titik jenuh. Yang terjadi adalah gelombang korupsi semakin marak dan menghebat. Jumlah koruptor non haji mungkin jauh lebih besar. ${ }^{8}$ Petualangan mereka dalam menggerogoti sendi-sendi

${ }^{7}$ Ungkapan ini pernah Syafii Ma'arif dengar dari prof Dr. H. Munawir Sjadzali sewaktu beliau berada di Montreal (canada), beri kuliah,bulan maret 1994, Inilah akibat dari melaksanakan haji hanya pada tataran sosiologi ritual bukan pada tingkatan totalitas, lihat Ahmad Syafii Maarif Membumikan Islam (Yogyakarta: Pustaka Pelajar, 1995), h. 156

${ }^{8}$ Ibid. h, 157

TAHDIS Volume 10 Nomor 1 Tahun 2019 
perekonomian dan keuangan negara dari hari ke hari semakin tidak dapat dikontrol. Sistem hukum kita yang sangat lemah telah dijadikan lahan yang subur untuk melakukan tindak kebiadaban oleh para petualang itu. Kolusi antara petualang dan birokrat (yang sebagian bertitel haji) telah semakin meringankan keadaan pada hal para birokrat telah ditatar P4, sebuah penataran yang gagal total memperbaiki kondisi moral bangsa.

Direktur-direktur Bank yang terlibat dalam kolusi di atas telah banyak disoroti mas- media. dan tidak jarang diantara mereka itu telah menunaikan ibadah haji. Seharusnya setelah pulang dari Mekah, seseorang telah menampilkan sosok yang memiliki integritas moral yang tangguh. Katebelece pejabat, siapapun pejabat itu, tidak boleh meruntuhkan iman seorang direktur bank, apalagi yang sudah haji, titel haji seharusnya menjadi tameng bagi seseorang untuk tidak berkubang dalam arus kehancuran moral. Uang negara sekian triliun menguap dengan mudah begitu saja berkat kolusi.

Bila negara tidak berani menyatakan perang total terhadap korupsi yang teramat parah ini, boleh jadi seorang rakyat miskin nun jauh di pelosok akan menadahkan tangannya ke atas sambil berdoa: Tuhanku! Apakah masanya belum tiba untuk kau luluh lantahkan para petualang ini hingga kami yang miskin ini sebelum menutup mata sempat juga hendaknya menyaksikan tegaknya keadilan- Mu. doa ini ku sampaikan oh Tuhan karena sistem pengadilan dunia tampaknya masih penuh kepura-puraan dalam menangani masalah korupsi yang sudah menjadi kanker masyarakat ini, Tuhanku! bila palu- godam keadilan-Mu mulai Engkau ayunkan, aku masih percaya bangsa ini akan segera taubat kepada-Mu. Oh Tuhan, tiada kekuatan lain kecuali Engkau ya Tuhan yang dapat mewujudkan jeritanku ini. Aku orang 
miskin, tapi aku masih punya kemampuan untuk berdoa kepada-Mu. Sesungguhnya Engkau Maha Mendengar, Maha Mengetahui".

Harapan kita selanjutnya tentu saja doa semacam ini akan didengar oleh mereka yang sudah terbiasa berkolusi dan kemudian kembali ke jalan yang benar sebelum segalanya terlambat. Doa si miskin yang teraniaya akan diperhatikan Tuhan. Dan para haji yang terlanjur berkubang dosa juga sebelum segalanya terlambat, surutlah kembali ke jalan yang benar. Keadilan Tuhan tidak pandang bulu. Sangat berbeda dengan keadilan dunia yang penuh topeng dan kong kali kong.

\section{Kesimpulan}

Setelah diadakan pemikiran dan penelitian yang mendalam tetang judul makalah haji budaya dan budaya haji perspektif sosio-filosofis, maka akan diberikan beberapa kesimpulan penelitian

Pertama, Haji budaya adalah pelaksanaan haji yang dilakukan oleh setiap umat Islam yang berkemampuan totalitas, secara hakiki ritualistik, spiritualistik dan nilai-nilai sosialistik yang dilakukan oleh orang-orang yang berhaji adalah sebuah budaya.

Kedua, Para pelaksana haji baik yang berkemampuan lebih atau yang memaksa diri dalam rangka meraih tingkatan mabrur sebatas pada ritualisme belaka dan tidak memberikan nilai implikasi dari ke-hajiannya, merupakan budaya haji yang hura-hura mengejar prestise bukan prestasi dan kualitas. Hal inilah yang merusak kehidupan kemanusiaan secara individu dan kelompok seperti melakukan penyimpangan sepulang dari melaksanakan haji antara lain korupsi, kolusi dan nepotisme yang tidak wajar untuk dilakukan oleh para haji-haji.

TAHDIS Volume 10 Nomor 1 Tahun 2019 


\section{DAFTAR PUSTAKA}

Ahmad Syafii Maarif Membumikan Islam (Yogyakarta: Pustaka Pelajar, 1995) Muchtar Adam, Tafsir Ayat-ayat Haji : Telaah intensif dari pelbagai Mazhab (Bandung: Mizan, 1993)

Darmawan Mas'ud Rahman, Konsep Kebudayaan Islam di Dalam Budaya Nasional dan Global (Suatu Kajian Teoritik Menggugah Definisi Budaya Masa Kini Untuk Masa Mendatang) Orasi Ilmiah Pengukuhan Jabatan Guru Besar Disampaikan Pada Dies Natalis XXXV (IKIP Ujungpandang tanggal 1 Agustus 1996)

M.Qurash Shihab, Membumikan Al-Quran : Fungsi dan Peran Wahyu dalam Kehidupan Masyarakat, (cet; 13, Bandung;Mizan, 1996)

Nurcholish Madjid et al Kontekstualisasi Doktrin Islam Dalam Sejarah (Jakarta: Paramadina, 1994)

Ibn Katsir, Tafsir Ibnu Katsir, Jilid III. 